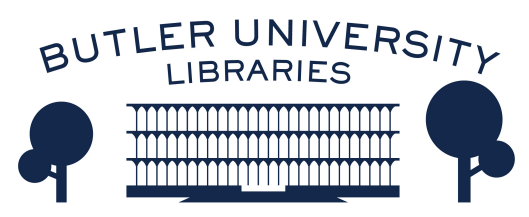

Journal of Hindu-Christian Studies

Volume 5

Article 8

January 1992

\title{
Viewpoints: Hindu-Christian Dialogue in Austria/Vienna as a Typical Example for Interreligious Dialogue
}

Birgit Langer

Follow this and additional works at: https://digitalcommons.butler.edu/jhcs

Part of the Religion Commons

\section{Recommended Citation}

Langer, Birgit (1992) "Viewpoints: Hindu-Christian Dialogue in Austria/Vienna as a Typical Example for Interreligious Dialogue," Journal of Hindu-Christian Studies: Vol. 5, Article 8.

Available at: https://doi.org/10.7825/2164-6279.1061

The Journal of Hindu-Christian Studies is a publication of the Society for Hindu-Christian Studies. The digital version is made available by Digital Commons @ Butler University. For questions about the Journal or the Society, please contact cbauman@butler.edu. For more information about Digital Commons @ Butler University, please contact digitalscholarship@butler.edu. 


\title{
VIEWPOINTS
}

\section{Hindu-Christian Dialogue in}

\section{Austria/Vienna as a Typical Example for Interreligious Dialogue}

\author{
Birgit Langer, University of Vienna
}

\section{Different Levels of Dialogue}

ACCORDING TO THE Indian Embassy at present 4800 people from India live in Austria. Among them are approximately 1000 Hindus. Most of the Hindus live in Vienna. Hinduism does not belong to the religious communities - like Islam or Buddhism - which are acknowledged by the Austrian State. Therefore Hindu children, who visit Austrian schools, are registered with the notice "no religion." In Austria Hindus represent a very small minority. Nevertheless several institutions and organisations are occupied with Hindu-Christian dialogue in quite different ways.

As early as 1967 the De Nobili Research Library was initiated at the Institute of Indology, University of Vienna. The name relates to the Italian Jesuite Roberto De Nobili (15771656), who worked as a missionary in India. It is the task of this Research Library to prepare the scientific foundation for the dialogue between the world religions, especially between Hinduism and Christianity. Since 1972 a series of publications on the subject is edited ("Publications of the De Nobili Research Library.") In the meantime a respectable list of publications exists. Scholars of different countries especially of India have the possibility to publish their studies relating to the specific problems of the De Nobili Research Library. In addition to the publication activity international conferences between representatives of Indology and Christian Theology are organised.
Up to now four conferences on the subjects revelation, experience of transcendence, salvation and hermeneutics have taken place. The papers of these conferences are also published in the De Nobili Series. ${ }^{1}$ The next conference will be held in autumn 1992. Although the main purpose of the De Nobili Research Library is research work in the underlying principles of interreligious dialogue, there exists a certain awareness to contribute in the long run to solve the practical questions of the living-together between people of different cultures and faiths.

A second institution for scientific-based interreligious dialogue is established at the Philosophical and Theological High School St. Gabriel, Mödling near Vienna. Since 1975 every second or third year study-conferences between representatives of Christianity and either Islam, Buddhism or Hinduism are organised. The different contributions to these conferences are published as volumes of the series "Beiträge zur Religionstheologie," edited by the High School St. Gabriel. Up to now one study-conference was dedicated to HinduChristian dialogue. It took place in the year 1983 under the title "Sein als Offenbarung in Christentum und Hinduismus" (Being as revelation in Christianity and Hinduism). The papers were published under the same title in the following year. ${ }^{2}$ In contrary to the De Nobili conferences in St. Gabriel Hinduism is represented exclusively by Hindu scholars. In addition to this difference the spiritual dimension 
of dialogue is cared for in St. Gabriel. There is some time reserved for reading and contemplating sacred texts of both religious traditions in dialogue.

Not research in problems of interreligious dialogue, but engagement for the common human value of world peace is the main interest of the World Conference on Religions and Peace (WCRP). In 1988 an Austrian section of the international organisation was founded in Vienna. Mutual understanding is of great importance for this interreligious group. Therefore regularly meetings on special subjects like "The responsibility of man for life" or "The Holy Scriptures - their relevance for religious life" take place. In May 1991 the European Assembly of WCRP was organised at Mödling near Vienna. As general theme the following question was chosen: "Towards Partnership in Europe and the World: Do Religions have a Role?" In the course of the meeting not only the importance of Judaism and Islam was considered, but also the influence of Hinduism and Buddhism on European mind was realized. The dialogue with these religions was pointed out to be a necessity for the future of Europe and the new finding of identity. In this way the Hindu-Christian dialogue is part of a wider interreligious dialogue close to problems of daily life.

The most vivid form of Hindu-Christian encounters in Vienna is possible in the AfroAsian Institute. This is a Catholic organisation for the care of students from developing countries. The institute maintains two hostels for students, wherein a Christian chapel, a Muslim prayer-room and a Hindu-Mandir are established. On saturdays the Hindu temple is a place for interreligious encounters. Besides the reading from Hindu scriptures also prayer and meditation are practised. The celebration of Hindu feasts like Dasserah, Divali and Holi and other activities as a series of lectures on different Hindu topics help to set up the interest in Hindu-Christian dialogue.

\section{Dialogue and the Importance of Information}

The situation of Hindu-Christian dialogue in Vienna is more or less typical for the whole world: Interreligious dialogue is taking place on different levels. There exists the dialogue of working together for serving general human welfare. At several universities and other educational or research centers round the world the academic dialogue of the religious experts is located. Moreover people of different faiths meet to come into the dialogue of religious experience. The promoters of this spiritual dialogue tend to underestimate the importance of plain information about religions. Spiritual dialogue today is the affair of an elite only. For most people it is true that Dialogue first aims at better mutual understanding, precision of one's own religious viewing point, mutual enrichment and eventually engagement in common interests. This sort of dialogue subsists on two necessary preliminaries: information and abolishment of prejusdice.

With regard to these facts it is interesting to examine how people get information about other religions. Besides mass media and different institutions for further education, in Austria information about the world religions is part of the Christian religious instruction in school. Relating to Hindu-Christian dialogue I would like to add some remarks on the presentation of Hinduism in Austrian school books.

As an example I choose secondary school. The Austrian curriculum for Catholic religious instruction ${ }^{3}$ prescribes information and discussion of Hinduism for pupils of the first and the fourth class. In the first class - at the age of 15 years - Christian pupils have to be informed about the world religions. The main purpose lies in the transmitting of knowledge about other religions and a better understanding of one's own tradition. The other religions have to be evaluated from the viewpoint of the Catholic Church. The corresponding school book ${ }^{4}$ for the first class throws some spotlights on Hinduism. The authors characterize Hinduism as "verwirrende Vielfalt"5 (confusing multiplicity). There are some remarks about the divergent imaginations of god and gods respectively. Further information is given about Samsara, Karma, Moksha, castes and outcasts, religious practice, veneration of the cow and Mahatma Gandhi. The chapter concludes with hints about the history of Christianity in India including the appreciation of "Mutter Theresa." 
The dialogue with the world religions is part of the curriculum ${ }^{6}$ for the forth class - for pupils at the age of 18 years. Our time, it is said, demands dialogue and calls for tolerance. In this connection stress is laid on the following aims of the religious instruction. The pupils should realize the common tasks of the religions of mankind. Possibilities and ways for interreligious dialogue should be brought to view. As fundament for the dialogue reference is made to the declaration "Nostra aetate" of Vaticanum II. In this context of Dialogue teachers are required to explain how the Christian order to mission has to be understood nowadays. In the corresponding school book the success of dialogue depends on the acceptance of the "true and holy" in the other according to the declaration of the council. Dialogue is located between tolerance and the common looking for truth. In the following a special form of dialogue is presented. It starts with reference to the common of two religious traditions and ends in the understanding of the difference. As an example for Hindu-Christian dialogue the topic of incarnation and Avatara ${ }^{8}$ respectively is presented. The short passage ends with the question, does the Avatara-concept help to understand the Christian teaching of incarnation? In accordance with the curriculum, the chapter about dialogue includes several texts relating to the Christian understanding of mission.

I conclude this short explication with some critical hints and impulses for further consideration. In the first case mentioned, Hinduism is dealt with as one religion. This is a source of many difficulties in understanding. According to their own understanding of religion Christians tend to harmonize the different religious traditions of India. Unfortunately it is not taken into account, that Hinduism originally is derived from a geographical term, the Persian name for the river Sindhu/Indus. The word Hinduism describes therefore no religious self-determination like Buddhism or Christianity. It would be better to treat Hinduism as a collective name for different religious traditions.

Serious misunderstanding results from missing the distinction between the levels of popular religion and theological reflection.
Without regard to the different theological systems the representation of Hinduism can only result in a structureless confusion. If dialogue has the aim to understand each other, it would be necessary to put the self-understanding of each religious tradition in the centre of consideration. As a consequence there should be some room for self-interpretation.

In the second case the difficulty is even more obvious. The christocentric perspective hinders the understanding of the actual meaning and position of the Avatara-concept in Hindu traditions. It is misleading to compare the centre of Christian belief with a Hindu concept that does not hold such a prominent place in tradition. Moreover dialogue and missionary issues should be strictly separated. Otherwise dialogue could be misunderstood as a modern form of missionary activity. ${ }^{9}$

\section{The Risk of Dialogue - Dialogue at Risk}

Non-Christian Religions have a value of their own. After centuries of apology, neglect or even contempt the adequate Christian response to a religious pluralism slowly turns out to be respect and tolerance. Dialogue needs an attitude of open-mindedness, which can cause deep affections to one's own religious certitude. Dialogue remains monologue after all, if one's own convictions are left out of question.

Interreligious dialogue is a challenge. Yet the sincerity of dialogue itself is at risk, if dialogue is used as a means to emigrate to an island of religious self-satisfaction. Interreligious dialogue has to meet the provocations of modern self-understanding and world-view. And it has to cope with the fact, that religiousness is not bound to religious traditions but also exists outside. From a European point of view religions must learn to accept, that they have no monopoly of religiousness.

\section{Footnotes}

1 Concerning the following titles:

Offenbarung, geistige Realität des Menschen, Arbeitsdokumentation eines Symposiums zum Offenbarungsbegriff in Indien, hg. v. G. Oberhammer, Wien 1974.

Transzendenzerfahrung, Vollzugshorizont des Heils. Das Problem in indischer und christlicher 


\section{Viewpoints}

Tradition. Arbeitsdokumentation eines Symposiums, hg. v. G. Oberhammer, Wien 1978.

Epiphanie des Heils. Zur Heilsgegenwart in indischer und christlicher Religion. Arbeitsdokumentation eines Symposiums, hg. v. G. Oberhammer, Wien 1982.

The papers of the last conference are published by the Austrian Academy of Sciences under the title:

Beiträge zur Hermeneutik indischer und abendländischer Religionstraditionen. Arbeitsdokumentation eines Symposiums, hg. v. G. Oberhammer (Öst. Akademie der Wissenschaften. Phil.-Hist. K1. Sitzungsberichte 573: Beiträge zur Kulturund Geistesgeschichte Asiens 6)), Wien 1991.

2 Sein als Offenbarung in Christentum und Hinduismus, hg. v. A. Bsteh (Beiträge zur Religionstheologie 4), Mödling: St. Gabriel, 1984.

3 Lehrpläne für den katholischen Religionsunterricht an AHS (Kommentierte Ausgabe 1983), hg. v. Interdiözesanen Amt für Unterricht und Erziehung.
4 Hörmandinger, J./ Karlinger, A./ Trojan, L., Wem glauben? Religion AHS 5. Klasse, hg. v. Interdiözesanen Katechetischen Fonds, Innsbruck: Tyrolia, 1985 , pp. 39-44.

5 Ibid., p. 39.

6 Cf. note 3.

7 Riebel, M./ Salmen, J./ Zwinz, H., Lebenswege Glaubenswege. Religion AHS 8. Klasse, hg. v. Interdiözesanen Katechetischen Fonds, Wien: Herold, 1989, pp. 108-121.

8 Avatara literally means descent (from $a v a-t \bar{r}$. to descend), appearance of a deity upon earth. Cf. M. Monier-Williams, A. Sanskrit-English Dictionary, Reprint Delhi: Motilal Banarsidass, 1990, p. 100.

9 With regard to the actual importance of this problem cf. the article of G. Evers, Interreligiöser Dialog und Mission nach der Enzyklika "Redemptoris Mission," in: Zeitschrift für Missions-und Religionswissenschaft 75 (1991), pp. 191-209. 